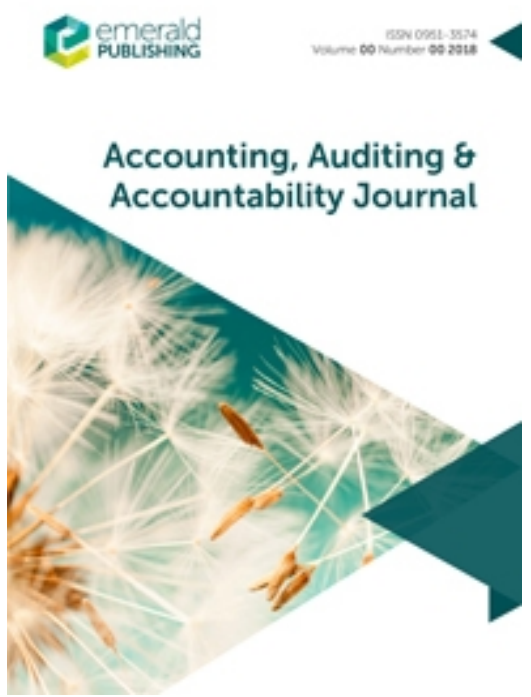

\title{
Call to Service: The Register of Australian Accountants for National Service 1940-1944
}

\begin{tabular}{|r|l|}
\hline Journal: & Accounting, Auditing \& Accountability Journal \\
\hline Manuscript ID & AAAJ-10-2019-4200.R2 \\
\hline Manuscript Type: & Research Paper \\
\hline Keywords: & $\begin{array}{l}\text { World War 2, national service, register of accountants, accounting } \\
\text { services, volunteerism, legitimacy }\end{array}$ \\
\hline \multicolumn{2}{|l}{} \\
\hline
\end{tabular}

\section{SCHOLARONE ${ }^{m}$ \\ Manuscripts}




\title{
Call to Service: The Register of Australian Accountants for National Service 1940-1944
}

\begin{abstract}
Purpose - The paper explores the creation in Australia of the Register of Accountants for National Service. Established at the outset of World War 2, the Register operated for four years from June 1940 providing voluntary, non-remunerated, part-time and after-hours services to a highly stressed and seriously stretched Federal Government bureaucracy by members of the main Australian professional accounting bodies. Departments of the Navy, Army, Air Force, Supply and Development and Munitions were the largest consumers of the services offered.

Design/methodology/approach - The study of the Register relies mainly on an extensive archive of war-time documentation from the Federal Government and various accounting professional institutes which has survived, predominantly in the National Archives of Australia. The resource is particularly rich in material covering the complex negotiation processes that brought the Register into operation together with documentation recording and reporting the work of the Register. The themes of professionalization, institutional legitimacy, volunteerism and patriotism are all invoked to explain the presence of the Register in the machinery of government that was assembled to deliver the ultimately successful war effort. Created by the principal professional accounting institutes, the Register attests to the commitment of their members to the war effort and, thereby, the importance of the profession to Australian society.
\end{abstract}

Research limitations/implications - Discussion focusses only on Australia where the Register was unique. No other examples have been discovered where a profession has self-mobilised to serve a nation in a time of war. A further limitation is that the activities reported are restricted to self-reporting by the Register and a small loose collection of documents prepared by the Department of the Navy.

Findings - The perilous situation of Australia at a time of war provided a compelling incentive for the accounting profession to organise itself in an efficient and highly effective manner to assist with the war effort. The disparate and somewhat fractured accounting profession at the time was able to work together in a structured, cohesive and disciplined manner to provide voluntary services when called upon. To deliver the voluntary services promised, a purpose-built set of institutional arrangements was put in place. An extensive inventory of the potential services that could be provided by members of the main professional accounting bodies was conducted to facilitate the smooth matching of government needs with services available.

Originality/value - The uniqueness of the Register is the core of the originality and value of this study. How and why it came into being and the method by which it completed the 'task' assigned to it stand as testament to a profession strategically placed to contribute in a substantive manner to the war effort at minimal cost to the nation. 


\section{2}

Paper type - archival research paper

Key words - national service; World War 2; register of accountants; accounting services; volunteerism; legitimacy 


\title{
Call to Service: \\ The Register of Australian Accountants for National Service 1940-1944
}

\begin{abstract}
"Australians have won their place with sacrifice, by miracles of production, by unstinted contributions ... and by an unswerving spirit of devotion to all tasks that war imposes."
\end{abstract}

\begin{abstract}
J.B. Chifley
Acting Prime Minister

Address to the Parliament - House of Representatives 8 May 1945 on the event of the declaration of V-E Day
\end{abstract}

\section{Introduction}

In July 1940 in response to the outbreak of war a register was created of Australian accountants who were members of the principal professional accounting bodies that constituted a form of national service. Officially designated as the Central Register of Accountants (hereafter the Register), the Register was created to provide the Australian Federal Government [1] with access to voluntary, unremunerated contributions from accountants. The initiative that became the Register was formalised on 1 July 1940 at a conference between senior representatives of the five principal accounting institutes and high-ranking officials of Federal Government departments [2] directly involved in the war effort. The Register was unique in that it is the only initiative discovered where a profession has been formally self-mobilised in the service of a nation during wartime [3]. Efforts in Great Britain during World War 2, for example, were made to manage the supply of accounting manpower through government sponsored agencies but not in the highly organised manner initiated by professional bodies that occurred in Australia (Armstrong 1987; Matthews et al., 1998). Volunteers on the Register were deployed to relieve pressure on government departments and improve efficiency of operations to meet the needs of a warbased economy. After a very active engagement by the Register with government departments in the early years of the war, contributions gradually reduced as departments became more able to contend with the exigencies of the war economy.

The successful establishment and operation of the Register as an instrument in the war effort between 1940 and 1944 confirmed that accounting practitioners had been not only able to navigate the professionalization process over many decades and emerge with the relevant 
attributes of a profession but, most especially, they had achieved a level of legitimacy within society that was critical to gaining the confidence of government in support of the initiative (Ashforth and Gibbs, 1990; Suchman, 1995). This legitimacy enabled the accounting profession to initiate action at a time of national crisis that would ultimately further enhance its standing in the eyes of the public. Grant's (2011, p.28) observation of World War 1 that 'the voluntary effort at home to support the men at the front ... remains a phenomenon about which little has been written' is particularly apposite when applied to the Australian accounting profession in the context of World War 2. While a few fleeting references to the Register are included in institutional histories (Australian Society of Accountants, 1962; Graham, 1978; Marshall, 1978; Linn, 1996), there is no mention of the Register in either the histories of the major accounting firms (Falkus, 1993; Armitage, 1995; Abrahams, 2001) or in the semi-official histories of Australia during World War 2 (Hasluck, 1952; Butlin, 1955; Butlin and Schedvin, 1977). The present study is the first to identify how the contributions of accounting in the management of war efforts during World War 2 were able to be strengthened by creating a professional body which would be able to enlist most advantageously these contributions.

The association between accounting and war has been attracting a growing interest by accounting researchers (Cobbin and Burrows, 2018; Chwastiak 2008, 2013; Funnell and Chwastiak, 2007). In this work the overwhelming focus is on the UK and to a lesser extent the US [4] and World War 1 and World War 2. Other literature in this genre extends from the Venice Arsenal of the late $16^{\text {th }}$ century (Zan, 2004; Zambon and Zan, 2007) to the more contemporary times of the Gulf War 2 [5] (Chwastiak 2008, 2013). The emphasis has been primarily on seeking understandings of how accounting enables the state to maintain military forces through constitutional, political and financial controls in times of peace and war. Financial controls not only manifest themselves with procurement of war materials from third parties by the military but also a willingness to embrace and adopt contemporary business technologies and practices (Miley and Read, 2012). The significant presence given to World War 2 in the literature has been mainly concerned with the impact of war on costing, particularly the manufacture of munitions (Fagerberg 1990; Fleischman and Marquette, 2003; Djatej and Sarikas, 2009; Cinquini et al., 2016) and the vexed question of efficiency in the procurement and supply of men and materiel (Tyson and Fleischman, 2006; Cobbin, 2009; Miley and Read, 2012; Djatej and Sarikas, 2009). A small number of studies have taken a critical view to implicate accounting in the promotion and sustaining of war-like activities. In particular a charge of culpability is levelled at the accounting discipline for its role in the 
perpetration of the Holocaust (Funnell, 1998; Lippman and Wilson, 2007) and the forced internment of Japanese-American citizens by the US government during World War 2 (Tyson and Fleischman, 2006).

This study draws on an extensive archive of primary source material preserved by the National Archives of Australia. Documents from the departments of Defence, Defence Coordination, Supply and Development, Army, Navy and Air are particularly relevant. Copies of reporting activities carried out by the General Registrar of the Register and the Department of the Navy are also retained by the National Archives of Australia. Evidence is also drawn from minutes of meetings of the General Council and Executive and National Committees of the various accountancy institutes involved with the Register. Details of the specific nature and extent of voluntary services provided by the Register are found in periodic reports by the Register and government departments. The final and most extensive reporting by the Register came at the end of the first year of operations in June 1941. As activity levels declined and the nature of the work changed in later years, the commitment to reporting similarly declined.

The next section of the paper provides an overview of the importance of legitimacy in the emergence of accounting as a profession in the middle of the $20^{\text {th }}$ century and how this ensured that the offer of service by the main accounting professional bodies was unhesitatingly embraced by the Federal Government. This is followed by an examination, invoking notions of altruism, legitimacy-seeking, volunteerism and patriotism, of how an unusual and unique initiative such as the Register developed into an organization of considerable benefit to the war effort. The operations of the Register from its creation in July 1940 until its closure in late-1944 are then discussed, followed by an assessment of the contribution made by those who volunteered their services.

\section{Professional legitimacy and the advent of war}

The pathway to professional status for the accounting discipline in Australia and its standing and legitimacy in the eyes of the Australian Government were inextricably linked to the progress achieved in Great Britain from Victorian times, where the first professional association, the Society of Accountants in Edinburgh, was established in 1854, and in the United States in 1887 with the formation of the American Association of Accountants. In Australia the first professional body of accountants was the Adelaide Society of Accountants, in the state of South Australia, established in 1885. In each jurisdiction the founding of accounting institutes was not only critical in the development of the discipline but also the 
crucible from which professional status was achieved, whereby the practitioners were accorded a high standing in society. At the outbreak of hostilities in 1939 the accounting profession in Australia was represented according to membership numbers, as shown in Table 1 below, by five principal accounting institutes and five minor institutes.

\section{Table 1 about here}

The process and related strategies by which occupations achieve professional status with related social and economic advantages has been debated, albeit inconclusively, at some length in the sociology of the professions literature. The amalgam of competing hypotheses and the extant research into professions and professionalisation is, as described by Meiksins and Watson (1989, p. 561), one with 'no single theory of the professions; rather, there are competing theories, no one of which has become completely hegemonic'. Meiksins and Watson (1989, p. 561) further observe that the 'most notable characteristic of this sociological research on professions ... is dissensus'. To navigate these competing theories, Willmott (1986) adopts a taxonomic approach that encapsulates three widely adopted theoretical genres; functionalist, interactionist and critical. Each approach gives a clear presence but a different emphasis or precedence to altruistic motives and recognises that, irrespective of the suggested primary motivations for gaining professional status, ultimately there will be benefits to members, both social and economic, that may not otherwise have been possible.

Drawing on a number of theorists [6], Willmott (1986) suggests that the functionalist viewpoint emphasises that a group of practitioners accorded the status of a 'profession' who are in possession of expertise and knowledge and who give a priority to maintaining independence, a commitment to altruism and a sense of self-discipline, will apply these traits to facilitate the smooth operation and functioning of society in which they are a part. However, the profession offers these attributes in exchange for high levels of prestige and other rewards. The interactionist understanding of professions, suggests Willmott (1986), is more focussed on the notion that professions carry out an occupational role in concert with their clients and colleagues that is crucial to establishing and maintaining the claim to professional status, which the interactionists conclude will justify better rewards. This view further asserts that members of the profession will exert deft political skills to retain legitimacy and standing in society that comes with professional status. Finally, the critical perspective asserts that members of the profession adopt a more mercenary approach to establish professional credentials consistent with a capitalist society. Invoking Weberian and 
Marxist ideology, the critical theorists according to Willmott (1988) suggest aspiring professions are fixated on achieving social status and the financial advantages that this will make possible by using the authority of their specialist knowledge to gain hegemony over an occupational domain. Notions of closure, exclusion, control, and solidarity abound within this domain.

In the theoretical approaches identified by Willmott, each of which encompasses in different measures the same key elements, professionalisation will not be motivated by one, all-encompassing aim. While there are differences between these understandings of what might be the primary motivations of particular occupational groups in seeking professional status, there is one important constant in the justifications that they provide; specialist, expert knowledge. West (1996, p. 82) observes that specialist knowledge as the common thread in the different theoretical understandings of professionalisation 'is persistently identified as either a benign but distinguishing trait of professions or, in the more critically inspired literature, the primary source of professional power'. Accordingly, a different priority is accorded to the relevance of specialist knowledge; whether in an altruistic sense, primarily allowing high quality service to clients and society, or for using the status that this provides for personal financial gain.

Irrespective of the suggested priorities of professional bodies, achievement of these on behalf of their members will depend upon these being consistent with the needs and expectations of the social and economic environment in which members provide their services. Recognition of the legitimacy of professional bodies and their members is 'dependent upon the good will (sic) and tolerance of the society of which they [professions] are a part' (Van Maanen and Barley, 1984, p. 318). Professions need to be constantly alert to and 'eternally vigilant' (Macdonald 1995, p. 204) of the need to work assiduously to retain standing. This has been clearly demonstrated with accounting professionals during times of major financial crises, such as during the Great Depression in the 1930's and the Financial Crisis of 2008, when accounting professionals were expected to take a leading role in restoring the financial well-being of not just individual private businesses but also that of the Nation itself. The present study shows that this association assumed even greater importance at a time of war with the creation of the Register. At a time of extreme national crisis, a time of war when the very survival of the Nation was threatened, less selfish, altruistic motivations for the accounting profession's commitment to the war effort were to be given an unquestioned priority. Thus, while ultimately achieving professional status may bring with it many advantages to members of professional bodies, this was not the reason for the creation 
of the Register. This was clearly recognised when preparations for the Register began very soon after the declaration of war and the Australian Government's 'all-in' policy was proclaimed with the need to begin immediate preparations to defend the country.

The institutes listed earlier in Table 1 were the legatees of a long and sometimes difficult evolutionary journey that many occupations have been confronted with as they strove to achieve professional status. Poullaos (1994, p. 219) has described the Australian experience as having been 'born of struggle and compromise, not to mention dangerous and difficult liaisons'. In the case of Australian accounting, half a century of mergers, amalgamations, takeovers and cessations among accounting practitioners had delivered a profession that was widely recognised as 'a legitimate organisation ... worthy, meaningful, predictable and trustworthy' (Suchman, 1995, p. 575), and thus well placed to make a substantive and, what Loft (1986) has described as, a constitutive contribution to the war effort if the circumstances permitted. The opportunity for, and capacity of, any assemblage of persons to successfully self-mobilise and serve in the national interest at a time of national emergency is predicated on two factors: an ability to set aside any enduring differences between constitutive bodies, and an established highly regarded reputation and standing with government, within the business community and the wider society.

Within the Australian accounting profession, long-standing internecine rivalries and residual resentments dating from the early years of the $20^{\text {th }}$ century characterised by three attempts to obtain a highly prestigious Royal Charter (Poullaos, 1994) [7] initially cast doubt on the capacity of the profession to make a collective, sustained contribution. However, despite these enduring differences, accountants had established a well-recognised professional standing and were integrated within the commercial and social fabric of the Nation (Lee, 1995). Therefore, as 'a powerful sector of the modern economy' (Lee, 1995, p. 64), they were in a strategically strong position to contribute to the war effort. Loft (1986, p. 137) argues that in the decades prior to World War 2 the accounting profession had 'come to play an important role in the working of modern society' and according to Burchell et al., (1980, p. 8) it had 'become an identifiable form of organizational and social practice'. This identity was the basis upon which the principal accounting professional institutes were able to offer successfully, their services to the Nation.

At the time that the professional bodies were offering the services of their members, the government was in the process of moving from a peacetime economy to a wartime economy. This transformation brought with it considerable challenges for government departments, particularly those in the defence realm, to improve efficiency in the delivery of men and 
materiel for the war effort. The legacy of the World War 1 efficiency scandals in the UK (Funnell 2005, 2006) and the exigencies of the new war accentuated the need to make this shift as quick and efficient as possible. Within the senior ranks of the defence bureaucracy the co-ordinated offer from the accounting profession came at an opportune time for they foresaw the opportunity to access a significant store of knowledge and competency possessed by the members of the profession. The government recognised that this significant 'body of specialist knowledge' (Carr-Saunders and Wilson, 1933, p. 307) or 'expert labour' (Abbott, 1988) could be readily and usefully deployed to ease this crucial transformation to a state of war. Government officials knew that they had a critical asset at their disposal without the need to divert urgently needed resources to organise the expertise needed. That the government was ready and willing to engage suggests it was not only acknowledging the standing of accounting as a profession but that it had every confidence the profession could deliver on the promises made.

Delivering the knowledge and competence base to government in the manner proposed enabled the profession to establish itself as a willing participant prepared to deliver selflessly any necessary services to the Nation. Although ultimately this would further consolidate and build on the standing and legitimacy that had already been achieved by the accounting profession, at a time when the Nation was fighting for its very survival the nature of the services provided and the close working relationship established with the relevant government departments confirmed that less altruistic intentions were not the primary motivation of the offer by the principal accounting institutes. The majority of services were to be delivered entirely out of business hours in members own time, located usually in secure premises with attendant security requirements, and provided on a pro bono basis at no cost to the government. As such, all participating members were sacrificing their own time in the interests of the Nation.

In the format that services were given as specified by the profession, the Register also provided a strategic advantage in that it provided a means of assistance that would not be constrained and denied the best possible contribution by strictures that were likely to be introduced if (and when) the government moved to introduce wartime regulation of the supply and management of all manpower resources, including accounting. Given that accounting as a discipline is complex (Burchell et al., 1980; Lee 1990), fragmented and diverse (Horovitz 1980 as cited by Hopwood 1983; Burchell et al., 1980; and Sikka and Willmott 1995), a specific-purpose institutional mechanism designed located and managed by those well acquainted with the associated specialist knowledge could arguably maximise the 
effectiveness and efficiency with which government might utilise the services on offer. In recognition of the apparent regard in which the accounting profession was held by government and acknowledging the complexity that was accounting, the government chose to cede entirely to the profession via the Register the co-ordination of the potential contributions of accountants in the interests of the war effort. It chose to take the exceptional measure of using the Register rather than the Directorate of Manpower in the Department of Defence Coordination that was ostensibly tasked to manage 'all' manpower resources in the economy on behalf of government. Once the confidence of government was assured and the decision was taken to proceed and that services would be overwhelmingly provided without charge, the opportunity was then available for the profession to put in place suggested institutional arrangements that were entirely consistent with societal expectations of professions by enlisting the higher-level characteristics of altruism, service and responsibility (Dowling and Pfeffer, 1975, paraphrased in Ashforth and Gibbs, 1990). This also potentially would maintain and extend the legitimacy already achieved (Ashforth and Gibbs, 1990).

\section{Formation of the Register}

The Register had its genesis in efforts by the Commonwealth Institute of Accountants [8] in December 1938 to signal at a time of growing uncertainty in Europe and Asia its unconditional 'willingness to cooperate with government to the fullest extent possible', following an indication by the government that it wanted to strengthen the defence services (S.W. Griffith, President, Commonwealth Institute of Accountants to J.A. Lyons, Prime Minister, Letter, 1 December 1938, NAA: A664 524/402/590 524/402/32). Despite support at the highest level, the proposal did not proceed and lapsed for the next eighteen months, to be overtaken by the outbreak of war. In the wake of a broadcast to the Nation on Sunday, 16 June 1940, in which the Australian prime minister R.G. Menzies extolled the virtue of the government's 'all-in' policy, the Commonwealth Institute of Accountants resurrected the idea of a co-ordinated effort by the accounting profession to assist the government. In acknowledgement of the social and political standing of the accountancy profession, the offer was accepted immediately with liaison responsibility passing to the Department of Defence Co-ordination and its fabled secretary F.G. Shedden (Horner, 2000) who recommended a centralized arrangement so that departments could draw help through a single agency. The accounting profession was to be the only profession during the war in Australia to create a body to marshal and co-ordinate the services which were provided by its members. Extensive contributions to the war effort were consistently made by members of other professions, such 
as engineers and medical practitioners, but not as part of a broad initiative by their relevant professional bodies.

The Register of Australian Accountants for National Service was formed on Monday, 1 July 1940 at the Department of Defence Co-ordination offices, Victoria Barracks, Melbourne, at which officials from government departments [9] and the main accounting institutes [10] attended. The task of chairing the gathering devolved upon a leading Melbourne-based chartered accountant, E.V. Nixon, who was highly regarded in government circles. Nixon, having been appointed Director of Finance in the newly created Ministry of Munitions, had recently relinquished chairmanship of the earlier disbanded Advisory Accountancy Panel in the Department of Supply and Development which had been established 'to advise on a scheme of costing and profit control for the production of munitions by private industry in an emergency' (Cobbin and Burrows, 2019). Acquainted personally with the prime minister R.G. Menzies, Nixon chaired the conference as the prime minister's personal representative delivering a prime-ministerial letter of commendation of the profession and the initiative (R.G. Menzies, Prime-Minister to The President of the Commonwealth Institute of Accountants, June 22 $2^{\text {nd }}$ 1940, NAA: A1608 R31/1/1). The minutes of the meeting indicate that the focus was the creation of a general scheme confined to the five largest, and therefore principal, professional accounting institutes which were the participating bodies, excluding the five minor institutes (Minutes of Meeting of Presidents and Registrars of Accountancy Institutes held on Monday $1^{\text {st }}$ July 1094, NAA: MP504 236/702/104).

The decision to engage with the five main accounting associations had its genesis in the earlier decision to appoint the Accountancy Panel in the Department of Supply and Development. F.G. Shedden, Secretary of the (then) Department of Defence, where the panel was initially proposed before the establishment of the Department of Supply and Development, had sought advice about the standing of the various accountancy bodies in a series of personal communications with a long-time friend H.J. Trist of H.J. Trist and Stranger, Chartered Accountants, Sydney, between December 1938 and February 1939. They eventually settled on the five institutes with the largest membership, and thus most extensive reach and penetration in Australian business. These institutes, which the government referred to as the 'principal' institutes, were subsequently invited to nominate members to the panel in March 1939 [11].

A Central Committee created for the Register, composed of the presidents of the five principal institutes, formed the national coordinating body. C.W. Andersen, National 
Registrar of the Commonwealth Institute of Accountants, was appointed General Registrar with overall national administrative responsibility. Committees and registrars were established in each state and several tasks were identified for immediate action:

(i) preparation of a working constitution,

(ii) conduct a survey of members' readiness to serve,

(iii) preparation of a Classification of Accountancy Services and,

(iv) design of a system to record the services that members could provide.

While no formal title was given to the Register's constitution it was referred to as the Plan of Organisation. Conduct of the survey was the responsibility of the Central Committee, with the compilation of registers to be undertaken by each of the Registrars appointed in each state. A letter explaining the initiative was prepared in the names of the five participating institutes and sent to all members with the signature of each of their presidents on the Central Committee. Documents were modified to reflect local characteristics and to engender a sense of local association. The letter exhorted involvement and advised that 'Government departments are finding it increasingly difficult to cope with the growing volume of accounting work. Accountants ... can give valuable assistance in the present national emergency by making their services available' (Circular, National Service, undated, NAA: A663 O130/2/574). The questionnaire accompanying the letter was laid out in three sections covering General Information, Honorary Services and Remunerated Services. Initially designed to ascertain availability for service, it also sought specifics of experience in the accounting and auditing fields. A copy of the questionnaire is shown below as Figure 1.

\section{Figure 1 about here}

The brief given to the Register by the government encompassed three service options : high level consultancy, location-specific support and full-time personnel placement. The first, which was mainly for a select number of senior members of the profession, was to undertake work of an administrative, advisory or consultative nature. Although no elaboration was provided, the structure of a questionnaire suggests that this service was likely to be fee-for-service [12]. The second service option, the main focus of the Register, was directed to all members able to offer honorary services of a general accountancy or auditing nature. Initially tasks were likely to be relatively low-level and repetitive, including checking or general assistance in accounting but more complex tasks emerged in due course. This type of service could be rendered during the daytime but was more likely to be rendered in the 
evening, depending on members' availability. The third option, which was for those able to take up full-time remunerated service, required a different level of commitment. In this latter option members of the five principal accounting institutes who had special knowledge of cost accounting, factory organization and management were targeted. Demand was expected to be limited as recruiting was restricted to the Department of Supply and Development and the Ministry of Munitions and salaries were unlikely to be commensurate with those paid in private industry. Thus, it can be seen that those who would leave any present employment to undertake these positions were making a decision that was mainly altruistically motivated; a desire to serve their nation in its time of need by responding 'generously to the call for national service' (Anon., 1941, p. 449). The second form of service listed provided the basis for the reports prepared by the Register. On-going maintenance and advancement of the national Register was also vested in local officials drawn from the contributing institutes who were expected to establish lines of communication with government departments.

The next major task was the preparation of a Classification of Accounting Services (hereafter Classification) to facilitate matching and allocation of expertise and experience to the needs in government departments. The Classification, which is replicated in Appendix I, was the means to inform government departments of services available. Developed in two stages, it initially identified Primary Classes of services followed by a series of Secondary Classes within each Primary Class. Eleven Primary Classes of accounting services as identified by the Register (see Part A of Appendix I) were categorised along industry sector lines. Primary Classes 1 and 2 were mainly reserved for members either practicing in or employed by accounting firms. Primary Class 1 - Administrative and Consultative, was reserved for senior practitioners and senior accounting executives in commerce who were judged to have exceptional experience and ability in their fields of expertise. If the detail provided by members did not match the expectations of Class 1 they were classed as Primary Class 2 - General Accountancy and Auditing. The majority of members placed in Primary Class 2 were drawn from the middle and junior ranks of accounting firms but it also served as a catch-all for members who did not qualify under any of the remaining Primary Classes. Primary Classes 3 to 5 related to secondary industries, Class 6 to primary industries and Classes 7 to 10 tertiary industries. Class 11 covered those in government and municipal service. Limitations associated with the Primary classes became apparent very early during the processing of over 1,000 Victorian member registrations. To alleviate the problem an additional 74 mutually exclusive sub-classifications called Secondary Classes were identified for Primary Classes 3 to 10. These are listed under Part B of Appendix I. As Primary Class 
11 was restricted to public servants and municipal officers who were deemed not to be engaged in specialised work, no Secondary Classes were identified.

There is no evidence that members of the Committee based their work on any preexisting classification or taxonomy, although they may have drawn inspiration from some existing material as suggested by a brief comment in a Note to Secondary Class 3, Engineering. The note states that 'This classification embraces work of a highly specialized character. The fabrication of iron and steel is embraced by [Secondary] Class 5 (5) (See Commonwealth Year-Book 1939, page 735)'. In a time of emergency and when expediency was necessary, the Committee used the Classification to bring the Register to an operational level in a timely manner. The Classification was neither definitive nor exhaustive as gaps are observable in the numbering system to make provision for possible expansion but there is no evidence to suggest that they were used. This is the only known occasion of a large-scale effort to catalogue the skill base in the accounting profession.

The Committee recognised from an early stage the need for a system that would easily match expertise with need. This expectation was met via a single-sheet Visible Record System which was a machine-printed document manually prepared for each submission to the Committee by a stenographer after the completed questionnaires had been coded. The Visible Record System sheet (see Figure 2) was laid out with demographic detail on the first four lines together with Primary / Secondary classes from the Classification. Brief career-todate detail followed together with any specialist experience of Costing (denoted C) and / or Machine Accounting (denoted M). Details of the industry(ies) in which the costing experience had been gained were also sought. The final line of the sheet recorded additional demographic data, availability of members for service and the nature of service available according to the Classification. Colour-coded metal clips were also attached to the base of the card to facilitate identification of relevant personnel.

\section{Figure 2 about here}

When the Register was brought to an operational level, promotion of resources available was initiated by Shedden. Tactfully referring to the long hours being worked by department officials and the amount of overtime accruing, he let it be known throughout the defence realm that there was a pool of qualified accountants ready to give honorary service (NAA: MP508 236/720/104 S236/702/86). The chance to alleviate overtime and other pressures on government departments was obvious but Shedden was also acutely aware of the 
natural caution of public servants and the misgivings many held with engaging outsiders in the business of government. To encourage colleagues Shedden invoked the earlier-mentioned prime-ministerial endorsement along with some micro-level advice as to how voluntary accounting services might be usefully deployed. Typical tasks suggested by Shedden are listed in Table 2 below:

\section{Table 2 about here}

\section{The Register's first year - July 1940 to June 1941}

An extensive 25-page compilation report was produced by the Register for the first full year of operations, 1 July 1940 to 30 June 1941, including analysis across all states, departments and branches (Central Register of Accountants - Report of Voluntary Services to 30 June 1941 (One Year), NAA: A5954 371/1 and A663 0130/2/699). In a note appended to the report, the General Registrar recorded unequivocally that accountants on the Register who 'responded generously to the call for national service' were 'making a substantial contribution to the war effort' (Anon., 1941, p. 449). Andersen also conveyed the view to Shedden that 'the decision to establish the Register has justified itself beyond expectations' (C.W. Andersen, Secretary, Central Register of Accountants to F.G. Shedden, Secretary Department of Defence Co-ordination, Letter, 19 September 1941, NAA: A5954 371/1 O184/1/93). Extolling the virtue of, and foresight in, developing the Classification, the report also pointed to the ability of the Register to meet the needs of departments by matching expertise to task. This, the only report prepared, covered a period of constantly expanding activity and the greatest level of combined engagement by the accounting profession during the war. Composed of three parts, it included detail of the number of accountants registered, honorary service provided, costs incurred by the Commonwealth Institute of Accountants together with nation-wide summaries of work-in-progress and work completed. State-by-state and department/branch breakdowns were also included. The extent of the spread of registrations and the quantum of services delivered are summarized in Table 3 below.

\section{Table 3 about here}

The willingness to participate is evidenced by 3,070 members, or an estimated $22 \%$ of total membership of the participating institutes [13]. Victoria led the way, providing $33 \%$ of 
the total with New South Wales at 25\%, followed by Queensland, South Australia and Western Australia, all contributing approximately 13\% and Tasmania 3\%. In the first year 901 individuals contributed to work classed as complete whilst on-going commitments reported as ongoing work-in-progress involved 499 members. Summaries of work completed in the first year, as measured on an hourly basis by state, department and branch are shown in Table 4 below.

\section{Table 4 about here}

More than 31,000 voluntary hours were provided on completed work in the first year with activity reported in most states, across several departments, and different defence branches [14]. The state-by-state breakdown in Table 4, Panel A, shows the greatest usage of the service was in Victoria, accounting for $49 \%$ of work completed, while $27 \%$ was completed in Western Australia, 20\% in NSW and 4\% in South Australia. South Australian usage was particularly low, reflecting a concern expressed by the Deputy Director of Volunteer Service in that state to Defence Co-ordination in Melbourne that indicated 'Departments here fail to use the voluntary help available' (Deputy Director of Voluntary Services, Department of Defence Co-ordination, Adelaide to Director of Voluntary Services, Department of Defence Co-ordination, Melbourne, Memo, 19 November 1941. NAA: A663 O130/2/699). Thus, offers of service had been made but not all had been able to be implemented. The primacy of Victoria in the statistics is not surprising as the headquarters of all major defence-related departments were located in Melbourne, the capital city of Victoria. Victoria was also the main location of the manufacturing industry in Australia and most of the government munitions manufacturing facilities were also in the State. The Department of Army and Army Headquarters were also located at Victoria Barracks, Melbourne.

The spread in the usage of services provided by the Register was also reported in two additional ways. A summary of hours worked in certain departments, which is shown in Table 4, Panel B, confirms that in the first year the Department of Army accounted for the overwhelming proportion. At its peak the Register was servicing facilities on at least 44 air stations in all states except Tasmania. Branches of the armed services that utilised the Register are shown in Table 4, Panel C. Ordnance Branch and Finance Branch, including Treasury and Pay, accounted for most of the hours consumed. Within the Department of Army, Ordnance Branch $3^{\text {rd }}$ Military District (3MD) and the Master-General of the Ordnance $3 \mathrm{MD}$ consumed 10,236 hours alone whilst the $2^{\text {nd }}$ Australian Imperial Force Section of the 
District Finance Office (DFO) and Finance Branch, also at 3MD, consumed an additional 3,462 hours. In New South Wales the DFO in the $2^{\text {nd }}$ Military District consumed more than 4,000 hours and the respective office in Western Australia (5 $5^{\text {th }}$ Military District) accounted for nearly 5,000 hours. In total, more than $80 \%$ of all service reported in the first full year of operations was consumed by these four branches, all within Army.

For the months immediately following the report for the first year of the Register, ongoing commitment was evidenced through work-in-progress. The expected delivery of services reflected the patterns that had been established in the first year as shown in Table 5 below.

\section{Table 5 about here}

Table 5 indicates that as at 30 June 1941 there was an ongoing commitment to deliver 1,866 hours of service per week related to work that was currently in progress. If this were extrapolated to a full 52-week year a further 97,000 hours would have been delivered. However, this was not the reality for by the end of 1941 the services on offer by the Register and delivered were being scaled back significantly. There is also no formal reporting of service delivery in this period. As far as ongoing work in progress was concerned, as expected Victoria accounted for the largest number of hours with smaller contributions distributed unevenly over each of the other states (Table 5, Panel A). Dissection by department indicates again that the Army was the major consumer (Panel B). Ordnance, Finance and Aircraft Production were the major consumers of the services at the branch level (Panel C).

While the report for the first year of the Register provides an indication of the quantum and range of activities, a micro-level appreciation of the work assigned and duties undertaken by volunteers can be obtained from the General Registrar's descriptions in the report, a full listing of which is included in Appendix II. The listing reveals the extraordinary breadth of tasks performed. Some tasks were self-explanatory but in other cases there was less clarity. Procedures, documents or terminology would have been familiar only to those working within relevant areas of government.

\section{The evolving role of the Register post July 1941}

As the war progressed a second conference was scheduled for 21 November 1941 [15] with the surviving minutes portraying an organisation about to go through significant transition. Despite an unwavering commitment to the war, by late-1941 the level of voluntary 
service provided was adversely affecting the functioning of the accounting profession nationwide. In addition, there were significant consequences for the Register and the wider accounting community with the enlistment of accountants in the forces, two weeks attendance at Universal Training Camps, and the placement of qualified personnel into various governmental and service departments. From the outbreak of hostilities the profession had to contend with a constant stream of members enlisting for active or home service. Although this had not been part of the original brief given the Register, willingness to enlist placed great strain on the wider profession. Concurrently a second movement of nonconscripted [16] yet to enlist members into fulltime, remunerated, civilian government service consistent with the third element of the initial brief, significantly exacerbated the strain. At the same time, the profession was starting to encounter issues with delivery of services. The reality at the departmental level was that considerable advancement had been made in bringing the economy and bureaucracy onto a full functioning war-footing.

The potential impact of the difficulties facing the profession and the spectre of a diminishing supply of accounting expertise prompted some to counsel caution and suggest a more judicious and strategic approach to utilizing available personnel. A week later, on 28 November 1941, a third meeting was convened to consider the future of the Register and concluded that the need for utilising qualified personnel to carry out routine tasks may have passed but that there was still the possibility of retaining service at senior levels. This effectively set the agenda for the remaining tenure of the Register. The period in which a substantial and sustained effort was needed as the government, at a time of national emergency, placed the armed services on a more effective, efficient war footing had all but passed by the end of the first 15 months of operations. Although the Register continued operating for at least another 36 months, the second phase was characterised by a switch in focus to personnel placement and a reduced provision of voluntary services. No formal reporting was prepared by the Register in the post-1941 period.

From early-1941 the Directorate of Voluntary Services in the department of Defence Coordination maintained ongoing contact with the Register, monitoring all voluntary accounting services consumed by government. A series of brief reports prepared indicated 1,993 hours provided by the Register in Victoria in September to Navy, Army, Air, AuditorGeneral (Contracts Board) and Supply and Development, and 2,525 hours in October to Air and Navy (Director of Voluntary Services, Department of Defence Co-ordination, Melbourne. NAA: A663 O130/2/1067, 1099, 1228). Activity in Air and Navy was reported by the Directorate of Voluntary Services for each of November and December 1941 and 
January 1942, although hours used have not been discovered. No further Directorate of Voluntary Services reports are available for the remaining period. The Minute Books of the Commonwealth Institute of Accountants, Federal Institute of Accountants and the Australasian Institute of Cost Accountants include some references to continuing voluntary work but they are brief and provide no further detail other than the statistical information reported by the Directorate of Voluntary Services.

The scaling back of voluntary service by the Register coincided with a significant increase in the need to identify personnel to fill remunerated positions within government. As one of the initial tasks this had been a secondary issue for the Register in its early stages. Increased activity levels were reported in 1942 by the Commonwealth Institute of Accountants when it noted that the 'Public Service Inspector's Office was in constant touch with the Secretary and during the past year obtained from him information which admitted of appointments to the various Departments being made promptly' (Commonwealth Institute of Accountants General Council Minutes 1941, Minute No. 24, p. 4). For the first time the identification of personnel for full-time appointment had become the predominant role of the Register, driven by an extraordinary demand on the part of government to fill roles as the economy, and particularly the munitions industry, was scaled up to levels not previously envisaged. This pattern continued until late-1943 when the government introduced new Manpower Regulations that ceded to the Directorate of Manpower control over all occupations and trades including, for the first time, accounting.

Despite some residual activity, the tenure of the Register effectively came to an end in late-1944. This reality was acknowledged for the first time by the Federal Institute of Accountants when it noted that 'the original purpose ... had ceased to exist, and an attempt should be made to obtain the records relating to members of the Institute' (Federal Institute of Accountants Executive Committee, Minute Book, 1944). The Institute of Chartered Accountants in Australia came to a similar conclusion by confirming that "work is practically completed and that provision for the disposal of the records and assets of the Register would also be made' (Institute of Chartered Accountants in Australia National Committee, Minute Book Volume VIII, 20 November 1944, Minute No. 3284, p. 759). The proposals as put by the Federal Institute of Accountants and the Institute of Chartered Accountants in Australia to retrieve member-related information, dis-establish the Register and arrange for the disposal of all possessions brought the operation to finality [17].

\section{Discussion and concluding comments}


The unique nature of the Register of Accountants for National Service in a time of national emergency lies in the method of its creation, the way in which it was managed, the number and commitment of members who volunteered, several strategic decisions taken during its existence and possible legacies it created. The existence of the Register emphasises the preparedness of a group of individuals drawn from a profession previously riven with discord, disunity, resentment and mistrust who were able, through strong leadership, to put aside at a time of war the rancour that had bedevilled the profession in the two decades leading up to the outbreak of war. Encouraged by the prime minister at the time, the leaders of each of the participating accounting institutes put aside these differences and, in so doing brought together, under one agency, a resource that would be of great value to the Nation. The intervention of the accounting profession in the months prior to the outbreak of hostilities acknowledged an awareness of the precarious state of readiness within the government bureaucracy and a willingness to help relieve some of the pressure that was building on government department officials as they sought to bring the economy onto a fully functioning war-footing. The Register is an important event in Australia's journey through the war years as it was conceived at a time when the country was ill-prepared for war (Long, 1952; Mellor, 1958; Horner, 1996; Grey, 1999, 2001; Andrews, 2001; Palazzo, 2001; Stephens, 2001; Stevens, 2001).

The Register was not only a response to a dilemma confronting government officials but also senior officers of the accounting institutes whose members sought to render service to the Nation. As a natural progression of earlier moves dating from early 1938, it was a rational approach to organising the available resources for maximum benefit of the Nation. Fortuitously, the profession had planned early and the Register was brought into operation in a timely manner. In the absence of a properly coordinated effort by either the government or the profession, valuable, useful individual service might have been rendered, but the advantage derived from a disparate and potentially disorganised resource would have been limited.

The day-to-day operation of the Register was founded on rational principles as the Committees sought to optimize the matching of expertise to departments. This was achieved by firstly canvassing membership of the profession via survey to ascertain availability for service and the skill sets on offer. Secondly, an extensive Classification of Accountancy Services using industry as the primary means of differentiating experience and expertise was developed. This approach presumed accounting skill sets within industry groupings to be homogeneous and readily transferable within industries but not necessarily between 
industries. Descriptions based on functional expertise of different costing systems, pricing, inventory management, payroll record-keeping and machine-accounting could have been an alternative approach to take. Although this was not considered when developing the Classification, the survey elicited details of experience with costing and machine accounting. The functional approach, in a limited way, constituted a third dimension to coding when questionnaires were processed.

Success of the Register can be judged in several ways. In the first instance it was organised and well led from within the ranks of the Commonwealth Institute of Accountants. A strategic approach to planning was adopted utilising detail developed in the Classification, data collected via survey from members and departmental needs that had been identified. In this way the Register was able to target expertise to where it was desperately needed by matching, wherever possible, needs with expertise. Rather than providing personnel to only carry out mundane tasks, the Register sought to utilise to the fullest extent possible, the experience and specialist knowledge embedded within the membership that had registered for service. It responded to a desperate need for short term work to overcome backlogs and improve efficiency by marshalling a large cadre of personnel for voluntary service in a range of government departments and agencies. In quantitative terms, the Register achieved impressive outcomes. Overall $22 \%$ of the total membership was marshalled to serve. This measure would be significantly higher if those already in government service or enlisted in the armed forces could be identified to determine actual available members. The quantum of hours delivered by the Register was similarly impressive. More than 31,000 hours were delivered on tasks that were classed as completed and an additional indeterminate amount of ongoing works in progress were reported at the end of the first reporting period to the end of June 1941.

As a well-functioning war time bureaucracy emerged from the earlier difficulties, the need for voluntary services that was the staple of the first fifteen months of operation of the Register abated. As the needs of government changed so too did the focus of the Register. A transition occurred as the major focus moved from provider of mass voluntary services to, in the context of the time, a recruitment agency of exceptional reach. In response, senior officials at the Register were quick to shift their attention to a secondary brief that had been given by the government at the outset: the supply of accounting personnel into full-time remunerated roles. The Register was so successful in delivering this later role that it started to compromise the capacity of the profession to fulfil its role in the wider commercial world. The gravity of the situation was noted by the Chairman of the General Committee who 
reported 'a serious drain on commercial houses and practising firms' (Letter, C.B. Harvey, Chairman of the General Committee of the National Register of Accountants to Lieut. General Sir Carl Jess, Chairman Manpower Committee, Department of Defence Coordination, 26 March 1941, NAA: A663 O130/3/708). This role remained with the profession through the Register until the middle of 1943 when regulatory changes saw the transfer of responsibility for the sourcing of accounting personnel for fulltime civilian service to the Directorate of Manpower Services. By this time the urgency that had bedevilled defence realm departments had been successfully addressed. While there are no benchmarks against which to compare and judge the contribution made, the very nature of the services provided, often at a strategic level by senior members of the accounting profession, had an important positive impact on the war effort. Consistent through this period of change was the final objective where the Register provided, on an as-needs basis, high-level consultancy and advisory services.

When peace was in sight in early 1944 government requirements moved quickly. Once the Register's usefulness had been exhausted the end was, predictably swift, and it slipped, with little fanfare, into abeyance. As with most special-purpose agencies created in war time no formal ex poste assessments were conducted, although the work and success of the Register had not gone unrecognised beforehand. Contemporaneous and reflective accolades recorded by senior public servants recognised that the Register had performed admirably. For example, J.T. Pinner, Commonwealth Public Service Inspector at the time who had worked closely with officials of the Register, noted that the Register and members 'have done a wonderful job in assisting the war effort on the Accountancy side' (Letter, J.T. Pinner, Commonwealth Public Service Inspector to F.G. Shedden, Secretary, Department of Defence Co-ordination, 22 August 1941. NAA: A5954 371/22). This vote of confidence was affirmed by T. Trumble, Director of Voluntary Services, who recorded that the Register has made 'a most valuable contribution to the war effort' and provided with an altruistic determination a 'fine record of patriotic service' (Memorandum, T. Trumble, Director of Voluntary Services to Deputy Directors - All States, 1 September 1941. NAA: A663 0130/2/699, 16926, 17075). In a similar vein C.G Brown, Chief Inspector, Finance in the Department of Defence Co-ordination, referred to the 'excellent voluntary service' that had been provided and alluded to the fact that 'sufficient prominence [was seldom given] to the security the public must necessarily feel when they know that the Service Departments, in their accounting transactions, are receiving the help and advice of members of the Accountancy profession' (Closing comments, Conference, 21 November 1941. NAA: MP508 
236/702/109). High level appreciation was also recorded with the prime minister paying 'tribute to the splendid voluntary work that had been performed by accountants anxious to assist in the war effort'. (R.G. Menzies, Prime Minister, File Note, 12 October 1940. NAA: A663 0130/2/656). Thus, the total effort mustered by the Register produced not only important outcomes for government, and by extension the Nation, but also for the profession itself.

In 'producing concrete, meritorious outcomes' (Suchman, 1995, p. 588), as evidenced by the positive reflections noted above, the precisely targeted contribution had further enhanced the profession's standing within society. The means by which the profession offered its services and the model of delivery, mostly costless to the country, conveyed commitment and service to the Nation and in the early days of the war it also provided an opportunity for service for members who had yet to enlist for home or active service [17]. Collectively the contribution enabled the profession to convey what Carr-Saunders and Wilson described in their seminal 1933 work as an important attribute of a profession, a 'sense of philanthropy [altruism]' (p.472). Not only was the profession and its members demonstrating a willingness to act in the public interest but they were also adopting a socially responsibility approach to service; behaviour which would also enhance professional standing in the eyes of the community. In this way, 'a sense of occupational honor through doing the public good' was achieved at this time of national crisis (Hughes, 1958, cited in Van Maanen and Barley, 1984, p. 302).

The activities of the Register also provided opportunities for members to act individually in a voluntary capacity. Musick and Wilson's (2008) six different motivators of this type of behaviour as articulated in their 'volunteer functions inventory' is particularly apt and provides further explanation as to why this initiative was ultimately successful. These include 'values [construed as] doing something for a cause', developing an 'understanding through personal growth and ego enhancement that provides a feeling of importance' and personal 'enhancement - the offer of learning experiences and to advance one's skills' (pp. 56-63). Each provided strong incentives for members to be involved.

The Register is important in the history and development of the accounting profession on several levels. Most importantly, the motivation of those who eventually served with the Register confirmed their sense of duty and, most significantly, professionalism in times of great stress, not only for themselves but also for the Nation. In the longer term, although not the conscious, determining objective of national service at a time when everyone's future was in obeyance, the Register was a well-conceived, effective means by which the accounting 
profession was able coincidently, in the best interests of the Nation, to enhance the legitimacy it enjoyed within the business community and wider community generally. It was at once a contribution made sacrificially but at the same time the profession arguably reaped an important dividend; enhanced legitimacy and standing within society.

As a first provider of voluntary services, accounting was an exemplar at the forefront of the professions at the time. The achievements made by the Register are significant in the history of accounting in Australia as they arguably helped to pave the way for a long period of, albeit competitive, cooperation by the major players in the profession in the second half of the twentieth century. Finally, and most importantly at a national level, the Register of Accountants for National Service and the members who volunteered played a vital role in the wider war effort and as one instrument of final victory contributed significantly to Australian society.

\section{Notes}

1. Australia is a federation of six states, two territories and a central government, referred to at the time as the Federal Government.

2. Included in the defence realm were Defence, Defence Co-ordination, Army, and Navy.

3. No evidence was discovered in the archive or reported in official histories of the war effort (e.g. Hasluck 1952, Butlin 1955, Butlin and Schedvin 1977) of any similar initiative by other professions.

4. Other countries include Australia, Canada, France, Germany, Ireland, Italy, Spain and the Soviet Union.

5. Gulf War 2 includes Operation Enduring Freedom - Afghanistan 2001 to 2014 and Operation Iraqi Freedom - Iraq 2002 to 2011.

6. For example: in the functionalist domain, Carr-Saunders \& Wilson 1933; Greenwood 1957; Parsons 1959, Ritzer 1963 and Barber 1963; in the interactionist domain Becker et al 1962; Haug \& Sussman 1963; Roth 1974 and in the critical domain Larson 1977; Klegon 1978 and Parkin 1979.

7. The third attempt (1922-1928) that proved successful in 1929 followed two earlier unsuccessful attempts, one by the Incorporated Institute of Accountants in Victoria (later Commonwealth Institute of Accountants) in 1904-1906 and a later attempt by the Australasian Corporation of Public Accountants in 1906-1914. Each of these attempts caused long-standing bitterness and resentment within the profession based primarily around the practitioner - non-practitioner divide, and the Melbourne - Sydney geographical divide (Poullaos 1994). 
8. The offer by the Commonwealth Institute of Accountants is the only one known amongst the accounting bodies. Others may have made similar offers and held similar sentiments, but none have been discovered in the archive and nothing is referenced in the negotiations that followed.

9. C.G. Brown, Chief Inspector of Finance of the Department of Defence Co-ordination; Department of the Army - Colonel Fordyce, District Finance Officer, $3^{\text {rd }}$ Military District Melbourne and Colonel S.B. Holder, Chief Accountant AIF; Department of the Navy F.H. Smith, Assistant Director of Naval Accounts.

10. Commonwealth Institute of Accountants - A.A. Fitzgerald - President, C.W. Andersen Registrar; Institute of Chartered Accountants in Australia - A.H. Outhwaite (as alternate of the president Sir Gordon Mason Allard) and J.R. Fullarton - Registrar; Federal Institute of Accountants - E.L. Wilson - President, G.T. Moore - Registrar; Association of Accountants of Australia (Inc) - R. Kinsman - President, C.W. Parkinson - Registrar; Australasian Institute of Cost Accountants - J.E. Morton - General President, J.R. McKenzie - State President, M.G. Roberts - Registrar.

11. The decision to engage with five accounting associations only, had its genesis in the earlier decision to appoint the Accountancy Panel in the Department of Supply and Development. F.G. Shedden, Secretary of the (then) Department of Defence (where the panel was initially proposed before the establishment of the Department of Supply and Development) had engaged in a series of personal communications with a long-time friend H.J. Trist of H.J. Trist and Stranger, Chartered Accountants, Sydney between December 1938 and February 1939. Shedden sought advice about the standing of the various accounting bodies and they eventually settled on the five institutes that were invited to nominate members to the panel in March 1939. The extensive personal correspondence between Shedden and Trist was lodged by both parties with the wider departmental documentation and is retained by the National Archives of Australia at serial A594, 972/1.

12. There is no evidence to suggest than any system of recording this activity was ever developed and so it is impossible to estimate the level of magnitude of the services provided or fees paid under this category.

13. This was the first and only occasion when registration numbers were officially reported by the Register. Membership of the participating institutes in 1940 was as follows:

\begin{tabular}{|l|c|l|}
\hline Accounting body & Membership & Source \\
\hline $\begin{array}{l}\text { Commonwealth Institute of } \\
\text { Accountants }\end{array}$ & $\begin{array}{c}5,000 \\
\text { (estimate) }\end{array}$ & Based on 4,300 known in 1938 \\
\hline Federal Institute of Accountants & 5,936 & $\begin{array}{l}\text { CPA Australia Archives } \\
\text { File: FIA003 }\end{array}$ \\
\hline $\begin{array}{l}\text { Australasian Institute of Cost } \\
\text { Accountants }\end{array}$ & 600 & $\begin{array}{l}\text { CPA Australia Archives } \\
\text { File: AICA001 }\end{array}$ \\
\hline
\end{tabular}




\begin{tabular}{|l|c|l|}
\hline $\begin{array}{l}\text { Institute of Chartered } \\
\text { Accountants in Australia }\end{array}$ & $\begin{array}{c}2,700 \\
\text { (estimate) }\end{array}$ & $\begin{array}{l}\text { Based on 1934 Membership } \\
\text { Booklet }\end{array}$ \\
\hline $\begin{array}{l}\text { Association of Accountants of } \\
\text { Australia, Inc. }\end{array}$ & unknown & \\
\hline Estimated total membership & 14,000 & \\
\hline Registrations & 3,070 & \\
\hline $\begin{array}{l}\text { Registrations as a \% of } \\
\text { estimated total membership }\end{array}$ & $22 \%$ & \\
\hline
\end{tabular}

14. Curiously Department of the Navy is not included at this point although there was considerable activity within Naval establishments in Sydney. A similar situation occurred with regards to Department of Air / Royal Australian Air Force. The hours reported are lower than actual as hours contributed to the administration and audit of Officers' and Sergeants' messes and Other Ranks' clubs and canteens have not been included. At its peak the Register was servicing facilities on at least 44 air stations in all states except Tasmania.

15. C.B. Harvey, chairman of the Central Committee (Institute of Chartered Accountants in Australia), A.A. Fitzgerald (Commonwealth Institute of Accountants), J.E. Morton (Australasian Institute of Cost Accountants), E.L. Wilson (Federal Institute of Accountants) and C.W. Andersen (General Registrar) represented the Register. Government was again represented by C.G. Brown, F.H. Smith and Col. S.B. Holder. H.C. Elvins and Flight Lieutenant L. Schofield represented the Department of Air and J.T. Pinner - Public Service Inspector represented the Commonwealth Public Service Board.

16. A limited form of conscription was introduced in Australia in November 1939 where unmarried, 21year old men were called up for three months training in the Militia (home defence). Militia personnel were not able to transfer to 2nd AIF (the de facto full-time Army - expeditionary force) nor were they allowed to serve overseas. After the declaration of war against Japan in December 1941 when the Nation came under direct threat of invasion, enlistments in both the Militia and $2^{\text {nd }}$ AIF increased significantly. In May 1942 the voluntary transfer of Militia personnel to the $2^{\text {nd }}$ AIF was permitted and in January 1943 the Militia were permitted to service overseas (defined as the near islands to the north and north-west of the continent - the South West Pacific Zone) (Hasluck, 1952; Dennis et al, 2008). Through this period larger numbers of members of the Register continued to enlist in all branches of the defence forces or were employed in full time positions in government departments and agencies. Membership of the Register did not afford an opportunity to avoid conscription

17. There is no evidence to suggest these documents have survived in the archives of either CPA Australia or Chartered Accountants Australia and New Zealand. 


\section{References}

\section{Primary Sources:}

\section{National Archives of Australia, series}

A663

A664

A1608

A5954

MP508

\section{CPA Australia Archives}

FIA003

AICA001

FIA Executive Committee Minute Book 1944

CIA Executive Committee Minute Books 1943

CAANZ Archives

National Committee Minute Books 1944

\section{Secondary Sources:}

Abbott, A. (1998), The System of Professions: An Essay on the Division of Expert Labor, University of Chicago Press, Chicago.

Abrahams, H. (2001), By All Accounts: The History of Ernst \& Young Australia 18842005, Ernst \& Young, Sydney.

Andrews, E. (2001), The Australian Centenary History of Defence, Volume V-The Defence Department, Oxford University Press, Melbourne.

Anon. (1941), "Central Register of Accountants: Review of work offirst year", The Australian Accountant, Vol. 1 No. 9, pp. 449-450.

Armitage, A. (1995), 100 Years: Smith Johnson \& Cop. To KPMG: 1895 to 1995, KPMG, Paddington.

Armstrong, P.(1987), "The rise of accounting controls in British capitalist enterprises", Accounting, Organizations and Society, Vol. 12 No. 5, pp. 415-436.

Ashford, B.E., and Gibbs, B.W.(1990), "The double-edge of organizational legitimation", Organization Science, Vol. 2 No. 2, pp. 177-194.

Australian Society of Accountants (1962), History of the Australian Society of Accountants and its Antecedent Bodies: 1887-1962, Australian Society of Accountants, Melbourne.

Barber, B. (1963), Is American business becoming professionalized? In Tiryakian, E.A., 9ed) Sociocultural Theory, Values and Sociocultural change: essays in honor of P.A. Sorokin, Free Press, New York.

Becker, H.S., Geer, B., Hughes, E.C., and Strauss, A.L. (1961), Boys in White, University of Chicago Press, Chicago. 
Birkett, W., and Evans, E. (2005), "Theorising professionalisation: a model for organising and understanding histories of the professional activities of occupational associations of accountants", Accounting History, Vol. 10 No. 1, pp. 99-127.

Burchell, S., Clubb, C., Hopwood, A., Hughes, J. and Nahapiet, J. (1980), "The roles of accounting in organizations and society", Accounting, Organizations and Society, Vol. 5 No. 1, pp. 5-27.

Butlin, S.J. (1955), Australia in the War of 1939-1945, Series 4 (Civil), Volume III - War Economy 1939-42, Australian War Memorial, Canberra.

Butlin, S.J. and Schedvin, C.B. (1977), Australia in the War of 1939-1945, Series 4 (Civil), Volume IV - War Economy 1942-45, Australian War Memorial, Canberra.

Carr-Saunders, A.M. and Wilson, P.A. (1933), The Professions, Oxford University Press, Oxford.

Chwastiak, M. (2008), "Rendering death and destruction visible: counting the costs of war", Critical Perspectives on Accounting, Vol. 19 No. 5, pp. 573-90.

Chwastiak, M. (2013), "Profiting from destruction: the Iraq reconstruction, auditing and the management of fraud”, Critical Perspectives on Accounting, Vol. 24 No. 1, pp. 32-43.

Cinquini, L, Giannetti, R. and Tenucci, A. (2016), "The making of uniform cost in a war economy: The case of the Uniconti Commission in Fascist Italy", Accounting History, Vol. 21 No. 4, pp. 445-471.

Cobbin, P.E. (2009), "The best brains of the public accounting world": The restricted membership of the Army Accountancy Advisory Panel, 1942-1945", Accounting Historians Journal, Vol. 36 No. 2, pp. 1-29.

Cobbin, P.E. and Burrows, G. (2018), "The profession of arms and the profession of accounting numbers - accounting, the military and war: a review", Accounting History, Vol. 24 No. 4, pp. 487-520.

Cobbin, P.E. and Burrows, G. (2019), "A progressive traditionalist: Sir Edwin Van-DerVord Nixon CMG, Accountant, (1876-1955)", Accounting History, Vol. 25 No. 1, pp. 134159.

Dennis, P., Grey, J., Morris, E., Prior, R. and Bou, J. (1995), The Oxford Companion to Australian Military History, Oxford University Press, South Melbourne.

Djatej, A. and Saritas, R. (2009), "The Second World War and Soviet accounting", Accounting History, Vol. 14 Nos. 1 and 2, pp. 35-54.

Dowling, J. and Pfeffer, J. (1975), "Organizational legitimacy: social values and organizational behavior", Pacific Sociological Review, Vol. 18 No. 1, pp. 122-136. 
Fagerberg Jr, D. (1990), “A World War II cost accounting assignment”, Accounting Historians Journal, Vol. 17 No. 1, pp. 81-88.

Falkus, M. (1993), Called to account: a history of Coopers \& Lybrand in Australia, Allen \& Unwin, St. Leonards.

Fleischman R. and Marquette R. (2003), "The impact of World War II on cost accounting at Sperry Corporation", Accounting Historian Journal, Vol. 30 No. 2, pp. 67-104.

Funnell, W.N. (1998), “Accounting in the Service of the Holocaust", Critical Perspectives on Accounting, Vol. 9 No. 4, pp. 435-464.

Funnell, W. (2005), “Accounting on the frontline: cost accounting, military efficiency and the South African War", Accounting and Business Research, Vol. 35 No. 4, pp. 307-326.

Funnell, W. (2006), "National efficiency, military accounting and the business of war", Critical Perspectives on Accounting, Vol. 17 No. 6, pp. 719-751.

Funnell, W. and Chwastiak M. (2007), "Call for papers - accounting and the military". Accounting History, Vol. 12 No. 1, p. 123.

Gavens, J. J. (1990), An historical perspective of integration of the Australian accounting profession. In Parker, R. H. (Ed.). (2013). Accounting in Australia (RLE Accounting): Historical Essays. Routledge, 381-407.

Graham, A.W. (1978), Without Fear or Favour: A History of the Institute of Chartered Accountants in Australia 1928-1978, Butterworths, Sydney.

Grant, P. (2011), "Voluntarism and the impact of the First World War", in Hilton, M., and McKay, J. (Eds), The Ages of Voluntarism: How we got the Big Society, Published for the British Academy by Oxford University Press, Oxford, pp. 27-46.

Greenwood, E. (1957), “Attributes of a profession”, Social Work, Vol. 2 No. 3, pp. 45-55.

Grey, J. (1999), A Military History of Australia, Cambridge University Press, Cambridge.

Grey, J. (2001), The Australian Centenary History of Defence, Volume 1 - The Australian Army, Oxford University Press, South Melbourne.

Hasluck, P. (1952), Australia in the War of 1939-1945, Series 4 (Civil), Volume I - The Government and the People, 1939-42, Australian War Memorial, Canberra.

Haug, M.R. and Sussman, M.B. (1969), "Professional autonomy and the revolt of the client", Social Problems, Vol. 17 No. 2, pp. 153-160.

Higgins, T.G., and Olson, W.E. (1972), "Restating the ethics code: a decision for the times", Journal of Accountancy, March, pp. 34-39.

Horner, D. (1996), Inside the War Cabinet: Directing Australia's War Effort 1939-45, Allen and Unwin in association with the Australian Archives, St. Leonards. 
Horovitz, J.H. (1980), Top Management Control in Europe, Macmillan, London.

Horner, D. (2000), Defence Supremo: Sir Frederick Shedden and the Making of Australian Defence Policy, Allen and Unwin, St. Leonards.

Hughes, E.C. (1958), Men and their work, Free Press, Glencoe.

Klegon, D. (1978), "The sociology of professions: an emerging perspective", Sociology of Work and Occupations, Vol. 5 No. 3, pp. 259-283.

Larson, M.S. (1977), The rise of professionalism: A sociological analysis, University of California Press, Berkeley.

Lee, T.A. (1990), "A systematic view of the history of the world of accounting”, Accounting, Business and Financial History, Vol. 1 No. 1, pp. 73-107.

Lee, T.A. (1995), "The professionalization of accountancy", Accounting, Auditing and Accountability Journal, Vol. 8 No. 4, pp. 48-69.

Linn R. (1996), Power, Progress and Profit: A History of the Australian Accounting Profession, Australian Society of Certified Practising Accountants, Melbourne.

Lippman, E. and Wilson, P. (2007), "The culpability of accounting in perpetuating Holocaust", Accounting History, Vol. 12 No. 3, pp. 283-303.

Loft, A. (1986), "Towards a critical understanding of accounting: the case of cost accounting in the U.K., 1914-1925", Accounting, Organizations and Society, Vol. 11 No. 2, pp. 137-169.

Long, G. (1952), Australia in the War of 1939-1945; Series 1 (Army), Volume I - To Benghazi, Australian War Memorial, Canberra.

Macdonald, K.A. (1995), The sociology of the professions, Sage, London.

Marshall N.J. (1978), A Jubilee History, 1928-1978, Institute of Chartered Accountants in Australia - Victorian Division, Melbourne.

Matthews, D., Anderson, M., and Edwards, J.R. (1998), The priesthood of industry: the rise of the professional accountant in British management, Oxford University Press, Oxford.

Meiksins, P.F., and Watson, J.M. (1989), "Professional autonomy and organizational control: The case of engineers", The Sociological Quarterly, Vol. 30 No. 4, pp. 561-585.

Mellor, D.P. (1958), Australia in the War of 1939-1945, Series 4 (Civil), Volume V-The Role of Science and Industry, Australian War Memorial, Canberra.

Miley, F. M., and Read, A. F. (2012), "The implications of supply accounting deficiencies in the Australian Army during the Second World War", Accounting History Review, Vol. 22 No. 1, pp. 73-91. 
Musick, M.A., and Wilson, J. (2008), Volunteers: A social profile, Indiana University Press, Bloomington.

Palazzo, A. (2001), The Australian Army: a history of its organisation 1901-2001, Oxford University Press, South Melbourne.

Parkin, F. (1979), Marxism and Class Theory: A Bourgeouise Critique, Tavistock, London.

Parson, T. (1939), “The professions and social structure”, Social Forces, Vol. 17 No. 4, pp. 457-467.

Poullaos, C. (1994), Making the Australian Chartered Accountant, Garland Publishing, New York.

Ritzer, G. (1972), Man and his work: conflict and change, Appleton-Century-Crofts, New York.

Roth, J.A. (1974), "The sociologist's decoys", Sociology of Work and Occupations, Vol. 1 No. 1, pp. 6-23.

Sikka, P., and Willmott, H. (1995), "The power of "independence": defending and extending the jurisdiction of accounting in the United Kingdom", Accounting, Organizations and Society, Vol. 20 No. 6, pp. 547-581.

Stacey, Nicholas A.H. (1954), English Accountancy: A Study in Social and Economic History 1800-1954, Gee and Company, London.

Stephens, A. (2001), The Australian Centenary History of Defence, Volume 1 - The Royal Australian Air Force, Oxford University Press, South Melbourne.

Stevens, D. (2001), The Australian Centenary History of Defence, Volume 4 - The Making of the Australian Defence Force, Oxford University Press, South Melbourne.

Suchman, M. (1995), "Managing legitimacy: strategies and institutional approaches", Academy of Management Review, Vol. 20 No. 3, pp. 571-610.

Tyson, T.N., and Fleischman, R.K. (2006), "Accounting for Interned Japanese-American Civilians during World War II: Creating Incentives and Establishing Controls for Captive Workers", Accounting Historians Journal, Vol. 33 No. 1, pp. 167-202.

Van Maanen, J. and Barley, S.R. (1984), “Occupational communities: culture and control in organizations", Research in Organizational Behavior, Vol. 6, pp. 287-365.

West, B. (1996), "The professionalization of accounting: a review of recent historical research and its implications", Accounting History, NS Vol. 1 No. 1, pp. 77-102.

Willmott, H. (1986), "Organising the profession: a theoretical and historical examination of the development of the major accountancy bodies in the U.K.", Accounting, Organizations and Society, Vol. 11 No. 6, pp. 555-580. 
Zambon, S. and Zan, L. (2007), "Controlling expenditure or the slow emergence of costing at the Venice Arsenal, 1586-1633”, Accounting, Business and Financial History, Vol. 17 No. 1, pp. 105-28.

Zan, L. (2004), "Accounting and management discourse in proto-industrial settings: the Venice Arsenal in the turn of the $16^{\text {th }}$ Century", Accounting and Business Research, Vol. 32 No. 2, pp.145-175. 


\section{APPENDICES}

\section{APPENDIX I - CLASSIFICATION OF ACCOUNTANCY SERVICES}

\section{PART A - Primary Classes}

\begin{tabular}{ll}
\hline Class & Class description \\
1. & Administrative and Consultative \\
2. & General Accountancy and Auditing \\
3. & Engineering \\
4. & Food, Drink and Clothing \\
5. & Other Industries \\
6. & Primary Productions \\
7. & Transport \\
8. & Wholesale and Retail \\
9. & Finance \\
10. & Public Utilities \\
11. & Government and Municipal
\end{tabular}

\section{$\underline{\text { PART B - Secondary Classes }}$}

Primary 3. Engineering

1. Mechanical (general)

2. Electrical

3. Construction

4. Railway and Tramway Workshops

Note: This classification embraces work of a highly specialised character.

The fabrication of iron steel is embraced by Class 5(b)

Primary 4. Food, Drink and Clothing

1. Butter, Cheese and Milk Products

2. Meat and Fish Canning

3. Bakeries and Biscuit Making

4. Fruit and Vegetable Preserving

5. Food Products

6. Confectionery

7. Grain Milling

8. $\quad$ Sugar Milling

9. Hotels and Restaurants

11. Tea, Coffee and Cocoa

12. Breweries and Aerated Waters

13. Wines and Spirits

14. Tobacco

16. Woollen Textiles

17. Cotton Textiles

18. Hosiery and other Knitted Goods

19. Tailoring and Clothing

20. Shirts and Collars

24. Boots and Shoes 
25. Headwear

Notes: Numbers have been provided for possible additions.

Item 4 includes jams, pickles, soups and sauces.

Item 9. These have been included because of the preparation of foods and drinks for consumption.

Primary 5. Other Industries

1. Chemicals and Drugs

2. Chemical Fertilizers

3. Soap and Candle Factories

4. Agricultural Implements

5. Iron, Steel and other Metals (Smelting and Fabricating)

6. Nonferrous Metals and Alloys (Extracting and Refining)

7. Motor Vehicles, Aeroplanes, Cycles and Accessories

8. Tyres and Rubber Goods

9. Electrical Appliances and Wireless Apparatus

10. Building Materials, Saw Milling and Construction

11. Paints and Varnishes

12. Ropes and Twine

13. Furniture and Upholstery

14. Household appliances and utensils

15. Tanning and Leather Dressing

16. Printing and Publishing

17. Paper, Pulp and Cartons

18. Amusements

19. Laundry and Dryers

20. Cannisters

Note: Item 5. See note under Class 3.

\section{Primary 6. Primary Production}

1. Agricultural

2. Pastoral

3. Dairy and Farmyard

4. $\quad$ Mining and Quarrying

5. Forestry

6. Fisheries

Note: Accountants to Wool Selling houses are included under "Pastoral" as these persons must have a good knowledge of the industry.

\begin{tabular}{|c|c|}
\hline Primary 7 & Transport \\
\hline 1. & Shipping \\
\hline 2. & Railways \\
\hline 3. & Tramways \\
\hline 4. & Motor \\
\hline 5. & Airways \\
\hline 6. & General \\
\hline
\end{tabular}

Primary 8. Wholesale and Retail

1. Importers, Exporters and Agents

2. Chain Stores 


\section{Department Stores}

4. General

Note: The secondary classification "General" has been used to cover such persons as newsagents, life assurance salesmen and others not associated with manufacturing or processing.

Primary 9. Finance

1. Banking

4. Trustee Companies

5. Building Societies

6. $\quad$ Friendly Societies

$7 . \quad$ Hire Purchase, Cash Orders and Loans

8. Sharebrokers

12. Insurance

13. Life Insurance

Note: Numbers have been provided for possible additions.

\section{Primary 10. Public Utilities}

$1 . \quad$ Gas

2. Electricity

3. Water and Sewerage

4. Fire Brigades

5. Hospitals and Asylums

6. Ports and Harbours 


\section{$\underline{\text { APPENDIX II - Task descriptions as reported by C.W. Anderson }}$}

\section{Department of the Army}

Headquarters - Finance Branch

Details of expenditure on works services at military camps

Soldier's allotments

District Finance Offices (AIF Section)

Checking extracts of paybooks [WF.5] with soldier's ledger cards

Checking soldier's acquittance rolls with summaries

Checking extract of page 2 of soldier's paybook with soldier's ledger card

Checking the WF.1 entry with the WF.3 soldier's ledger card and

WF.45 allottee's ledger card

Casual checking arising from day-to-day (unspecified)

General assistance in all departments

Records - increases in departmental allowances

Central Ordnance Depot

$$
\text { - compilation of credit earnings }
$$

Ordnance Branch - Accounts

$$
\text { Clothing records - past and present }
$$

Provision accounts - checking accounts for payment

Unit ledgers - entering from forms / posting

Stores ledgers - entering from forms / posting

Internal auditing

Stocktaking

\section{Department of the Navy}

Advice to transport section on shipping charges

Finance Branch

Service ledgers - checking balances and service

Particulars from one quarterly ledger to another

Posting character and ability assessments

Posting from Ship's ledger to reserve cards

Leave commission warrants

Allotments

Stores Branch

Outfit gratuities paid to Reserve Officers

Checking London vouchers

Accounts Branch

Checking and posting Stores / Stock Ledgers

Checking costs

\section{Department of Air}

Reconciliations between Pay Ledger postings and summaries of acquittances

Allotments

Pay (unspecified)

\section{Department of Supply and Development}

Analysis of appropriations

Checking overtime records

Aircraft Production Commission

Register of parts - checking group classifications

and entering symbols and supply centres on cards

Materials - checking classification to material specifications 
and calculating standard quantities in Production Department Planning Records

\section{Auditor-General's Department - Defence Section}

Assisting on systems of accounts in new departments

Pay office auditing - AIF pay DFO

Militia Camps mess audits

Contracts Board - checking buying procedures of the board

Audits / Inspections - various

Officer's and Sergeant's Messes

RAAF Semi-official accounts

RAAF Service Institutes (Canteens)

Unofficial funds on RAAF stations (43 in total)

Accounts at various Military Camps

Accounts of various Militia Units

Accounts at WAAAF unit

Voluntary Aid Detachments - headquarters statements

Australian Red Cross

Greek War Relief Special Day Appeal

Tin Hat Appeal - R.S.S.I.L.A.

WA Combined Charities Council

Spearfelt Patriotic Appeal

Women's Auxiliary of the Patriotic Fund

\section{Consultancy and Advisory}

Advice to Provision Section of QMG's Department on systems

Voluntary Aid Detachments

Instructing Commandants and Secretaries

Standardisation of accounts and statements

Preparation of list of Standard Rulings

Assisting in selection of personnel for War Departments - 90 positions

Supply of personnel to attend schools for inclusion in government accounting prior to taking up appointment

Assisting in selection of permanent officers for various arms

of the service

including Pay Corps and Ordnance

Advice to accountants on joining forces in an accountancy capacity

Advice to members contemplating enlistment

Assisting Minister of Munitions in the selection of personnel for costing work in Munitions Factories

Assisting District Finance Officers in the selection of permanent officers

Assisting in staffing of the Pay Corps from compulsory trainees

Other - various

Red Cross House - analysis of accounts

Navy House - control of cash takings

War Savings Offices - unspecified

Cafes for British children 
Accounting, Auditing \& Accountability Journal

Page 38 of 45

38

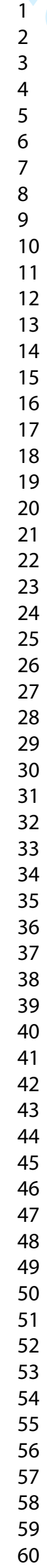




\section{FIGURE 1: QUESTIONNAIRE}
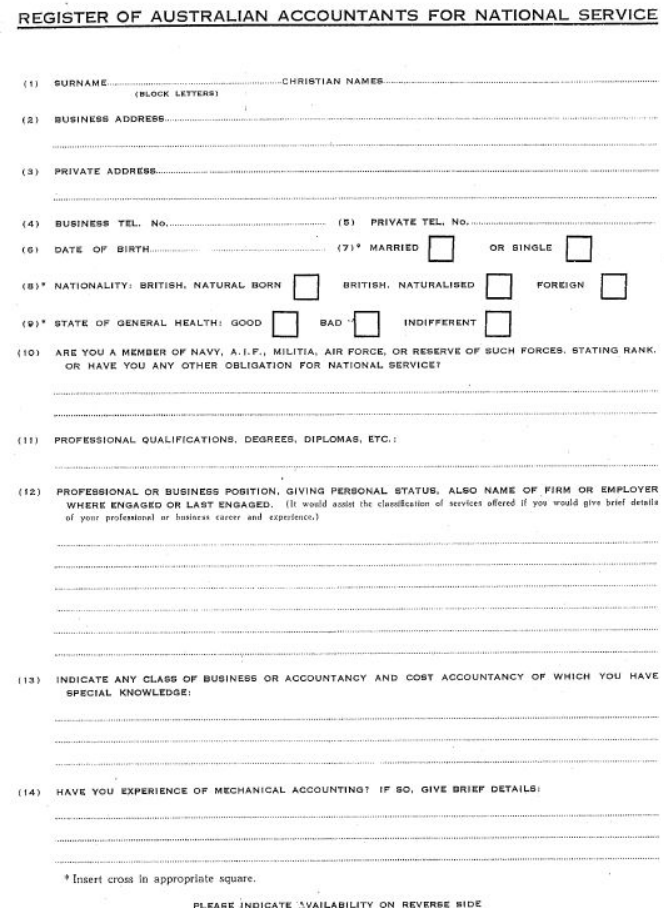

Source: NAA: A663 0130/3/708

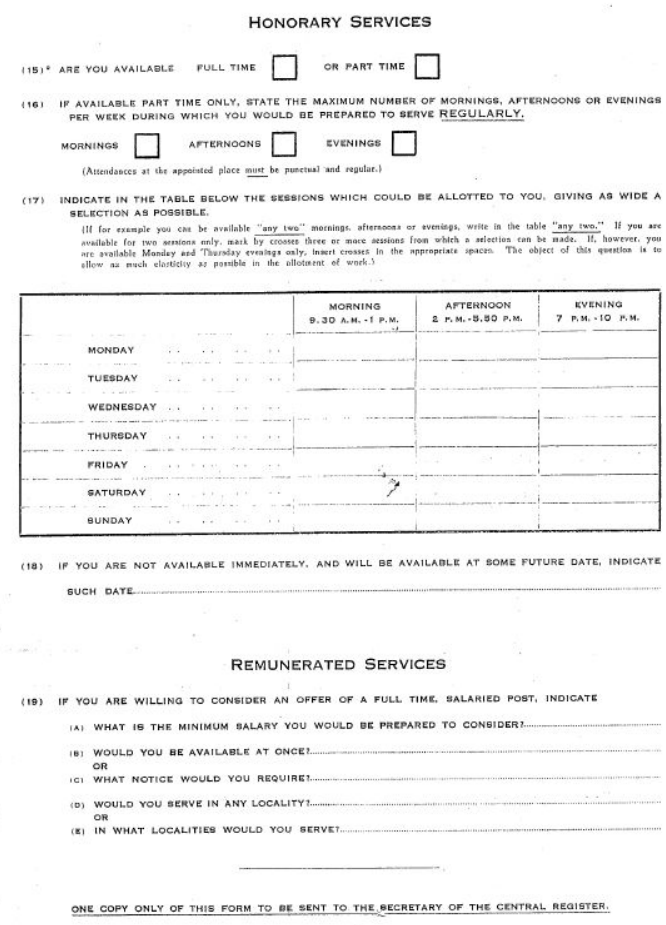




\section{FIGURE 2: (EXAMPLE) VISIBLE RECORD SYSTEM CARD}

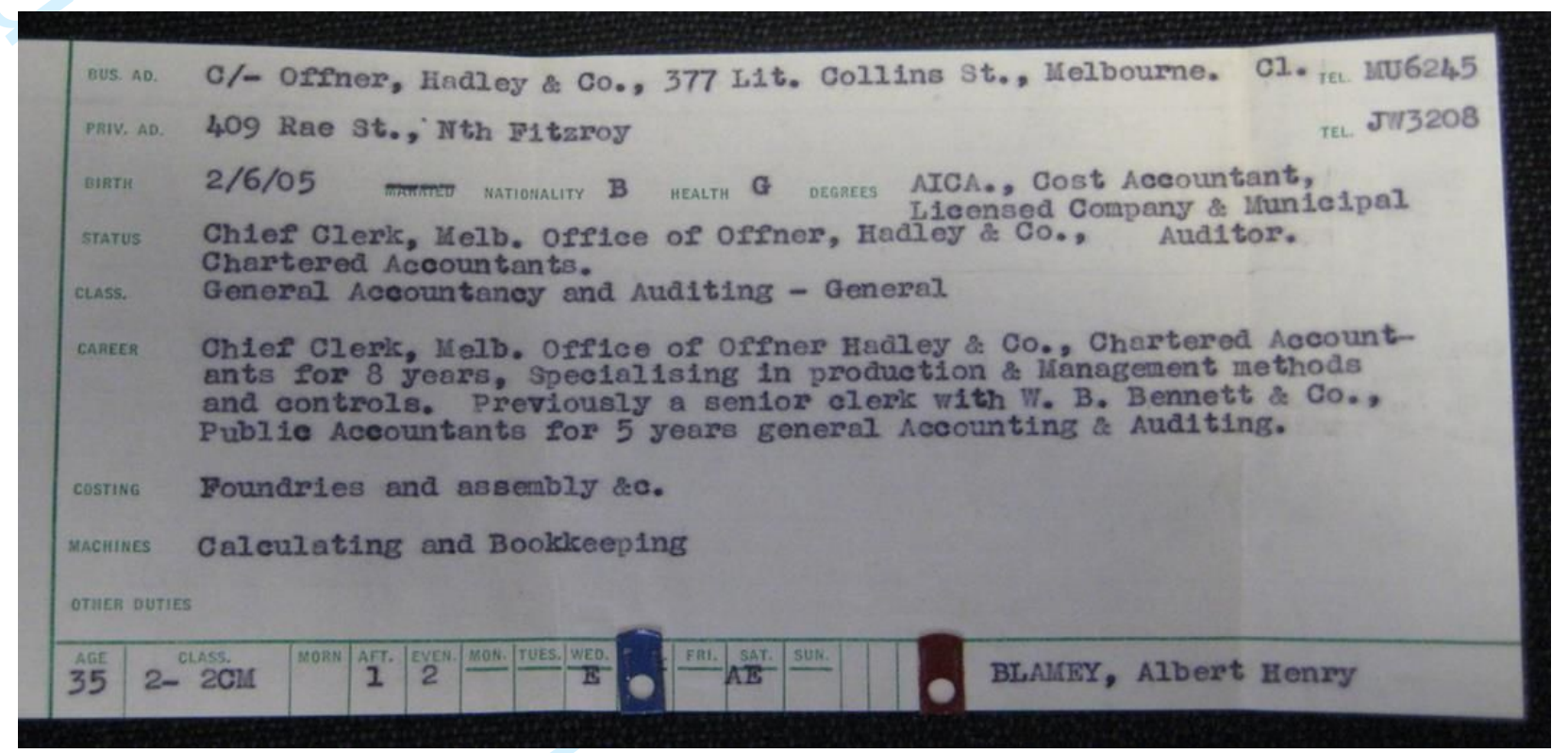

Source: NAA: MP508 236/702/104 


\section{TABLE 1: Australian accounting institutes extant in 1939}

\begin{tabular}{|l|l|}
\hline Principal institutes* & Minor institutes* \\
\hline Commonwealth Institute of Accountants & $\begin{array}{l}\text { Association of Practicing and } \\
\text { Commercial Accountants }\end{array}$ \\
\hline Federal Institute of Accountants & Corporation of Consulting Accountants \\
\hline $\begin{array}{l}\text { The Institute of Chartered Accountants } \\
\text { in Australia }\end{array}$ & $\begin{array}{l}\text { Institute of Factory and Works } \\
\text { Accountants }\end{array}$ \\
\hline $\begin{array}{l}\text { Australasian Institute of Cost } \\
\text { Accountants }\end{array}$ & Society of Commercial Accountants \\
\hline $\begin{array}{l}\text { Australian Association of Accountants } \\
\text { (Inc). }\end{array}$ & International Institute of Accountants \\
\hline $\begin{array}{l}\text { Source: Gavens } 1990 \\
(* \text { Note: separate descriptors are not per Gavens 1990) }\end{array}$ \\
\hline
\end{tabular}


TABLE 2: Task descriptions suggested by F.G. Shedden

\begin{tabular}{|l|l|}
\hline (i) & The checking of pay books against ledger cards \\
\hline (ii) & Reconciliation of the ledger card against the Allottee's ledger card \\
\hline (iii) & Check of Post Office reimbursements \\
\hline (iv) & Checking of Unit Regimental Accounts and Unit Stores Accounts (Army) \\
\hline (v) & Other checking work \\
\hline (vi) & Help at peak periods \\
\hline (vii) & Overtaking of any arrears of work \\
\hline (viii) & Special audits of services where payment is made on a cost-plus basis \\
\hline (ix) & Assistance in stock-taking \\
\hline (x) & Specials services and investigations as occasion arises \\
\hline $\begin{array}{l}\text { Source: } \\
\text { F.G. Shedden, Secretary, Department of Defence Co-ordination to the Secretary, } \\
\text { Department of Army, 16 July 1940. (NAA: MP508 236/720/104 S236/702/86) }\end{array}$
\end{tabular}


TABLE 3: REGISTRATIONS AND ENGAGEMENT

First Year of Operations 1 July 1940 to 30 June 1941

(by State)

\begin{tabular}{|c|c|c|c|}
\hline & Registrations & Completed Work & $\begin{array}{c}\text { Ongoing Work-in- } \\
\text { Progress }\end{array}$ \\
\hline Victoria & 1,019 & 374 & 187 \\
\hline New South Wales & 760 & 58 & 44 \\
\hline Queensland & 374 & $*$ & 26 \\
\hline South Australia & 398 & $*$ & 100 \\
\hline $\begin{array}{c}\text { Western } \\
\text { Australia }\end{array}$ & 399 & 469 & 18 \\
\hline Tasmania & 120 & $*$ & 499 \\
\hline Total & $\mathbf{3 , 0 7 0}$ & 901 & (Males 656; Females 245) \\
& & & \\
\hline
\end{tabular}

Source: Central Register of Accountants, Report of Volunteer Services as at 30 June 1941, p. 1. (NAA: A663, O130/2/699).

* Detail not reported 
TABLE 4: TOTAL HOURS WORKED ON COMPLETED PROJECTS

First Year of Operations 1 July 1940 to 30 June 1941

(by State / Department / Branch)

\begin{tabular}{|c|c|c|c|c|c|c|c|c|}
\hline \multicolumn{3}{|c|}{ PANEL A } & \multicolumn{3}{|c|}{ PANEL B } & \multicolumn{3}{|c|}{ PANEL C } \\
\hline BY STATE & Hours & $\%$ & $\begin{array}{l}\text { BY } \\
\text { DEPART- } \\
\text { MENT }\end{array}$ & Hours & $\%$ & $\begin{array}{l}\text { BY } \\
\text { BRANCH }\end{array}$ & Hours & $\%$ \\
\hline Victoria & 15,306 & (40) & Army & 29,061 & (94) & Ordnance & 16,401 & (53) \\
\hline $\begin{array}{l}\text { New South } \\
\text { Wales }\end{array}$ & 6,546 & (20) & Navy & $* *$ & & $\begin{array}{l}\text { Finance, } \\
\text { Treasury, } \\
\text { Pay }\end{array}$ & 12,621 & (40) \\
\hline Queensland & $*$ & & Air & 426 & (1) & $\begin{array}{l}\text { Aircraft } \\
\text { Production }\end{array}$ & 1,167 & (3) \\
\hline $\begin{array}{l}\text { Western } \\
\text { Australia }\end{array}$ & 8,610 & (27) & $\begin{array}{l}\text { Auditor- } \\
\text { General }\end{array}$ & 402 & (1) & $\begin{array}{l}\text { Other - not } \\
\text { specified }\end{array}$ & 1,176 & (4) \\
\hline $\begin{array}{l}\text { South } \\
\text { Australia }\end{array}$ & 603 & (4) & $\begin{array}{l}\text { Aircraft } \\
\text { Production }\end{array}$ & 1,167 & (3) & & & \\
\hline Tasmania & $*$ & & $\begin{array}{l}\text { Other-non- } \\
\text { departmental }\end{array}$ & 309 & (1) & & & \\
\hline TOTAL & 31,365 & (100) & TOTAL & 31,365 & (100) & TOTAL & 31,365 & (100) \\
\hline
\end{tabular}

Source: Central Register of Accountants, Report of Volunteer Services as at 30 June 1941, p. 1, 4-5. (NAA: A663, O130/2/699)

* Not reported; ** Listed but not reported 


\section{TABLE 5: HOURS COMMITTED PER WEEK - ONGOING WORK IN PROGRESS} First Year of Operations 1 July 1940 to 30 June 1941 (by State / Department / Branch)

\begin{tabular}{|c|c|c|c|c|c|c|c|c|}
\hline PA & EL A & & PAN & B & & PAI & L C C & \\
\hline $\begin{array}{l}\text { BY } \\
\text { STATE }\end{array}$ & Hours & $\%$ & $\begin{array}{l}\text { BY } \\
\text { DEPARTMENT }\end{array}$ & Hours & $\%$ & BY BRANCH & Hours & $\%$ \\
\hline Victoria & 708 & (39) & Army & 738 & (38) & Ordnance & 573 & (31) \\
\hline $\begin{array}{l}\text { New South } \\
\text { Wales }\end{array}$ & 138 & $(7)$ & Navy & 210 & (11) & $\begin{array}{l}\text { Finance, } \\
\text { Treasury, Pay }\end{array}$ & 693 & (36) \\
\hline Queensland & 200 & (32) & Air & 258 & (14) & Unallotted & 600 & (33) \\
\hline $\begin{array}{l}\text { Western } \\
\text { Australia }\end{array}$ & 264 & (14) & Auditor-General & 60 & (4) & & & \\
\hline $\begin{array}{l}\text { South } \\
\text { Australia }\end{array}$ & 78 & (4) & Unallotted & 600 & (33) & & & \\
\hline Tasmania & 78 & (4) & & & & & & \\
\hline TOTAL & 1,866 & $(100)$ & TOTAL & 1,866 & $(100)$ & TOTAL & 1,866 & (100) \\
\hline
\end{tabular}

Source: Central Register of Accountants, Report of Volunteer Services as at 30 June 1941, p. 1, 4-5 (NAA: A663, O130/2/699) 